\title{
INFORMATION SYSTEMS MANAGERS' VIEW ABOUT OUTSOURCING
}

\section{IN SPAIN}

\section{AUTHOR'S BIOGRAPHY}

Reyes Gonzalez (mr.gonzalez@ua.es) is a Senior Lecturer in Business Management and Information Systems at the University of Alicante. Her current research interests are Information Systems Management, E-Business and Outsourcing Processes. She has published articles in several journals, e.g. Information and Management, Information Technology and People, Logistics Information Management, Total Quality Management, The International Journal of Educational Management, Industrial Management \& Data Systems, and International Journal of Information Management.

Jose Gasco (jl.gasco@ua.es) is a Senior Lecturer in Business Management and Human Resources at the University of Alicante. His current research interests include Human Resources and Information Systems Outsourcing. He has published articles in several journals, namely, Revue Internationale P.M.E., Direction et Gestion des Entreprises, Corporate Communications: an International Journal, The International Journal of Public Sector Management, Business Process Management Journal, Total Quality Management, Information Technology and People, Logistics Information Management, the International Journal of Educational Management, and Human System Management.

Juan Llopis (juan.llopis@ua.es) is a Professor of Business Organisation at the University of Alicante. Among his current research lines stand out Organisational Culture, Human Resources, Quality Management, and Information Systems Management. He has published articles in journals like Information and Management, Total Quality Management, Journal of High Technology Management Research, Corporate Communications: An International Journal, Information Technology and People, Logistics Information Management Journal, International Journal of Value-Based Management, and Human Systems Management.

\section{CORRESPONDING AUTHOR}

Reyes Gonzalez. Department of Business Organisation. University of Alicante. Carretera San Vicente-Alicante. Zip Code: 03080. Alicante. SPAIN. Telephone and fax: 349659036 06. email: mr.gonzalez@ua.es. 


\section{INFORMATION SYSTEMS MANAGERS' VIEW ABOUT OUTSOURCING IN SPAIN}

\section{ABSTRACT \\ Purpose}

Outsourcing has been growing unstoppably all over the world in recent years. It is Information Systems (IS) managers that are having to face this phenomenon most directly in their departments. For this reason, our paper has as its aim to show IS managers' assessment of outsourcing in the Spanish case.

\section{Design/Methodology/Approach}

With this purpose, we have used the normative Delphi method with two rounds, showing the results obtained in the second round. The IS Managers of the largest Spanish firms were the experts interviewed in the study.

\section{Findings}

The experts interviewed suggest a widespread growth of IS outsourcing but describe a somewhat hostile environment around this phenomenon. This could be the reason why IS outsourcing has not developed in Spanish firms as much as those experts think is possible and even necessary.

\section{Originality/Value}

This paper offers the IS Managers' view about outsourcing and shows that they look at it as a way to improve their information services. The Delphi method, that has been often used in the IS field, helped us to confirm, in the second round, the conclusions that we had reached in the first round.

\section{KEYWORDS}

Information Systems (IS), Outsourcing, Delphi methodology, Spain. 


\section{INFORMATION SYSTEMS MANAGERS' VIEW ABOUT OUTSOURCING IN SPAIN}

\section{INTRODUCTION}

Information Systems (IS) outsourcing has been growing unstoppably in the last few years. Even though the years 2002 and 2003 were characterised by a slowdown in the information service outsourcing market, it still continued to grow at a considerable pace, according to the consultancy firm DBK (RrhhMagazine, 2004). Thus, after growing by $21 \%$ in 2001, the outsourcing market had growth rates of $19 \%$ in 2002 and $18 \%$ in 2003 , according to the same source. On the other hand, the consultancy firm Gartnet has predicted that the number of firms which will sign new IS outsourcing contracts will increase by $30 \%$ in 2004 (Frauenheim, 2004), and the Forrester company has forecast that european firms will spend over 128 billion euros on computer outsourcing services in 2008 (Forrester, 2004). According to the Penteo Group (2003), the Information Technology (IT) outsourcing sector moved 792 million euros in Spain in 2003, $14.5 \%$ more than in the previous year, the main providers of technological outsourcing service being Accenture, Cap Gemini Ernst \& Young, EDS, Gedas, HP, IBM, Indra, Informática El Corte Inglés (IECISA) and T-Systems, in this country.

IS outsourcing has finally come to be recognised as an irreversible phenomenon in our business environment and IS managers are the people having to face this phenomenon most directly in their departments. For these reasons, the objective of this paper is to explore how IS managers assess the key issues about outsourcing in the Spanish case. With that purpose, we have adopted a variant of the Delphi method as the source for data collection, interviewees being the IS managers of largest Spanish firms.

\section{METHODOLOGY: THE DELPHI METHOD}

The Delphi method was originally used to help predict the future of certain events and thus to provide the possibility of planning the future (Bradley and Steward, 2002). At present, the Delphi method is used both for future prediction and to throw light on current problems (pérez and Schüler, 1982: 167). In fact, we use Delphi in the latter sense in our research work. It is therefore a normative Delphi (Buckley, 1995).

The method consists in requesting a panel of experts to give their opinion in writing about a specific topic in a series of rounds, by means of various surveys or questionnaires, always 
anonymously. Each round provides feedback to experts on the results obtained in the preceding round, so that there is a chance for the panel to modify their previous answer, thus making it easier to reach a consensus with the other interviewees, or to stick to their own opinion (Bradley and Steward, 2002; Shi and Bennet, 2001:365; Dekleva and Zupancic, 1996:3; Gutiérrez, 1989: 32, Pérez and Schüler, 1982: 160). The successive rounds encourage reflection, favouring consensus and a more broad-minded approach on the part of the experts interviewed (Dexter et al., 1993). Anonymity allows participants to exchange ideas and preferences with no fear of being ridiculed and also reduces the problems associated with a potential pressure towards a consensus (Li et al, 2002: 277); panel members will express themselves more honestly because they need not worry about the consequences of their answers, and will avoid the influence exerted by the most dominant personalities.

The Delphi method has often been used as a research tool in the field of IS. In fact, recent studies support its use (Shi and Bennet, 2001; Okoli and Pawloski, 2004). However there is not agreement on the number of rounds and experts required to ensure that this method is reliable (Hayne and Polland, 2000: 75; Kaynak, Boolm and Leibold, 1994, Loo, 2002). This is why we can find applications of this method with 2, 3, 4 or more rounds and with an equally variable number of experts. It can also be inferred, from a review to the literature that uses this method, that the Delphi has been applied in numerous studies with normative and not only predictive purposes. For example, Pérez and Schüler (1981); Madu, Kuei and Madu (1991); Dexter et al. (1993); Doke and Swanson (1995); Dekleva and Zupanzic (1996); Keil, Tiwan and Bush (2002) and Mulligan (2002) among others, had used the normative Delphi in theirs IS research works.

In our research paper, we chose a normative Delphi method with two rounds:

First round: During the first round of this study, a questionnaire with 19 questions about IS outsourcing was sent to the IS managers of Spain's largest firms (ordered by sales). Although 4,416 questionnaires were sent by postal mail, the number of valid answers was 357 (8\%; sampling error: $5 \%$ ).

Second round: Following Dhaliwal and Tung (2000:135), after collecting interviewees' answers, the Delphi coordinator edits, clarifies, integrates and summarises the data. This is why, in our case, unlike what had happened in other studies, the second round did not consist 
in sending the initial questionnaire with the mean and the standard deviation corresponding to the answers obtained in the first round. Instead, those results were summarised and, on that basis, 10 reflections on IS outsourcing were made about which interviewees were asked to give their opinion. During this round, following what is proposed in recent studies (Bradley and Steward, 2002, 2003; Ventura Fernández, 2003), the questionnaire was sent by electronic mail to 49 IS executives who volunteered during the first round to collaborate once again in our study. Of those, only 15 (30.6\%) answered in this second stage. Their answers were received between July and October 2003. The number of answers can be considered acceptable, since according to recommendations in the literature, the final number of experts on a Delphi panel should be between 10 and 18 (Okoli and Pawloski, 2004:5). On the other hand, although three or four rounds would be advisable, we must bear in mind that the number of rounds is quite flexible in this method (Hayne and Polland, 2000:75); besides, panel members lose interest if too many rounds are demanded or if the study continues longer than expected (Loo, 2002).

\section{RESULTS}

Next we are going to show the main results obtained. Table I shows the general characteristics of firms and IS departments in which are located the experts interviewed in both rounds.

\section{Take in Table I}

Firm size can be measured by the number of employees and by sales. The interviewed firms are very large with respect to these two variables, since the lowest percentages are found in the smallest firms in both rounds. The vast majority of firms interviewed belong to the Industrial sector $(58.8 \%$ and $60 \%)$, followed by the Service sector and Financial and Insurance Institutions. Therefore, the experts interviewed come from all kinds of industrial sectors; in the case of the second round, among the industrial firms are found such sectors as chemicals, automotive, metal products manufacture, furniture, machinery or foodstuffs. As for service firms, we have retail trade and transports.

In the first round are represented firms from Spain's 17 Autonomous Communities (Regions); in the second round, although firms based on Madrid, Catalonia, the Valencian Autonomous Community or the Basque Country prevail, answers were also received from experts whose 
firms are located in Asturias, Navarre, Galicia, Canary Islands and Aragón (therefore, 9 out of 17 Autonomous Communities are represented).

Regardless of firm size, usually few staff work at IS departments. As can be seen in Table I, most firms have between 1 and 10 employees in their IS departments, and only very few firms have departments exceeding the figure of 100 employees in the first round; no firms with that IS department staff volume are represented in the second round. Likewise, the percentage of the total budget firms allocate to IS is quite low. It becomes equally visible in the same table that most firms dedicate between 0 and $4 \%$ of their budgets to IS, and only very few dedicate a percentage above $11 \%$, the maximum budget percentage allocated to IS being $30 \%$. In short, both IS department staff volume and the percentage of the budget dedicated to IS indicate that not many resources (neither human nor financial ones) are dedicated to these departments, which in turn suggests not very large department sizes.

Some of the characteristics of the IS manager -the expert we interviewed- suggest that this executive has held this post for 7 years on average. The IS manager's age is located around 41 years. These responsibility jobs continue to be predominantly taken by males. Regarding their hierarchical position inside the firm, more than half of the interviewees depend on the Chief Executive Officer, this position being the most often wanted, since it avoids the dependence on a specific functional area of the firm and allows having a more general view. Nevertheless, an equally significant percentage of answers show a dependence on Finance and Accounting, and less often on other areas, in both rounds. Something else that deserves to be highlighted in this table is the interviewees' length of service in their jobs, situated around 7 years (long enough to accept their expertise), as well as their provenance from different industries located in various geographical areas, so that these data can complement each other, as is required by the literature on this issue (Bradley and Steward, 2003).

\section{First Round Results}

As we said above, the questionnaire used in the first round had 19 questions, 14 of which were used in this research paper; 7 of these questions refer to the environment in which the outsourcing of the firms under analysis takes place, i.e. they refer to size (number of employees and sales), to the industrial sector, to the characteristics of both the IS department and the executive in charge of it, and finally to the top management's involvement in the IS of 
the respective firms. The 7 remaining questions specifically refer to the situation of outsourcing, that is, they identify what IS services are outsourced along with the outsourcing level, the main reasons and reservations of IS managers as far as outsourcing is concerned, and how the systems manager's job can be affected by outsourcing. As we said above, the questionnaire was answered by IS managers from 357 large firms. The results obtained are shown in Table I, to which we have already referred ${ }^{1}$.

\section{$\underline{\text { Second Round Results }}$}

After jointly analysing the answers given by the 15 participants in the second round to each of the 10 questions posed, we discovered that in most of them, more precisely 7, interviewees' answers could be grouped together around certain patterns. Table II shows the answer patterns identified for each question. In the other three cases (questions 4,6 , and 10), the heterogeneity of answers made it difficult for us to classify them as specific type answers. Let us now comment on the results of this second round.

\section{Take in Table II}

\section{The Environment around IS Outsourcing}

As for the environment in which IS outsourcing takes place, we have analysed the answers to questions 1 to 4 , which ask whether the human and financial resources allocated to IS departments are sufficient and whether the IS manager has a suitable position within the firm's hierarchy, and finally whether the Top Management gets involved in IS decisions. Concerning the first question, we can see that IS managers clearly see as too low the number of employees these departments have in the largest Spanish firms. In this respect, some interviewees argue: "in my opinion, the number of IS employees must be 5\% of the total staff", others point out that "this is due to the fact that most managers fail to perceive the critical importance of new technologies and are reluctant to keep highly-staffed IS departments"; a third interviewee suggests what he thinks would be the right ratio between computer experts on the staff and the outsourcing firm: "ideally at least $10 \%$ of the employees dedicated to development should belong to the firm's own staff, and preferably the project leader and the main analysts. The idea is that knowledge should stay "on the payroll"; a firm cannot be dependent on a person that can disappear overnight. Minimizing the number of

\footnotetext{
${ }^{1}$ Readers could apply for further details about the results of this first round to the corresponding author.
} 
employees entails a serious risk, because there is no replacement for anyone, and firms sometimes forget that employees die, get injuries, leave...".

However, some interviewees pointed out that this number of employees seemed adequate to them, as long as "the amount of equipment does not exceed the technicians' needs in terms of maintenance".

Other interviewees did not want to give a clear opinion in this first question and said that the staff volume may be adequate or not depending on: the number of users, the problems generated by the applications, and even the corporate culture.

As regards the financial resources allocated to IS departments (question 2), interviewees are even more categorical than in the first question, since $66.7 \%$ of them declare that the allocation is poor, while the remaining $33.3 \%$ considers it adequate. The justification for the first answer lies in the fact that "it is clearly insufficient; considering the possibilities offered by present-day technology, I think firms do not invest enough". Besides "large firms could become more competitive if their IS department had a budget located around 10\% of the firm's total budget", as "less than 10\% does not permit a continued evolution in new product development". However, one must also take into account the firm's circumstances: "if the computer system is stable and the firm only needs corrective maintenance, and sometimes evolutive maintenance by law, then $4 \%$ would suffice. If the firm wants to keep launching campaigns and products or introduce updates... at least $10 \%$ would be required".

The interviewees according to whom a percentage between 0 and $4 \%$ is adequate believe that "if the percentage is near $4 \%$, this seems to me a good situation in terms of budget allocation, less than $1 \%$ would be a poor budget in my view. The normal thing would be a budget located between 2\% and 3\%"; it should also be remembered that, as another interviewee points out, although he thinks the percentage is adequate "...it is not adequate if great changes and global plans are envisaged".

As for the third question, most of the experts interviewed (80\%) say that they do not like the fact that in one third of the largest Spanish firms, the IS manager has to report to the firm's Financial or Administrative areas, since "the appropriate dependence is on the General Management", as some interviewees point out. This is so "to avoid biases in computer work", as another interviewee explains, due to the "strategic weight" of the IS function. Some 
interviewees try to find the reasons for this hierarchical dependence: "I think this comes as a result of the growth experienced by organisations that have not gone through a reengineering process. These functional areas (Administration /Finance) are the ones where the introduction of the PC has been historically easier, but this situation should have changed". Besides, as others suggest, this dependence may be due to the fact that ITs are still seen as an expense that must be controlled: "I think it is wrong to consider computer systems as an expense that must be controlled, hence the frequent dependence on financial departments. Without computers, a company stops functioning completely and this fact very often goes unnoticed. It is also true that computer experts and business staff should find ways to be more in tune. In my view, improving this relationship becomes more difficult with the dependence on a financial department".

Nevertheless, two interviewees think that this dependence is correct; for example, one justifies his opinion saying that "in my firm, the greatest problems are related to ERP, SAP in our case, and all transactions end up in Finance".

It was difficult to identify a specific pattern for answers to question 4 , where it is said that the Top Management gets more involved in matters related to IS in smaller firms. We can find some revealing answers though:

"IS departments should be seen more often as a strategic factor for the firm"; for this reason, "in order to be successful, information systems must count on the support of the Top Management itself". Although some "top executives are starting to understand that it is very important to dedicate time to computer systems", "in larger firms, due to their stronger hierarchical position, executives have lost touch with the "real world" and IS is nothing but the daily functioning of a firm"; moreover, in these large firms, "the Top Management has to face great complexities in its decisions and is often forced to delegate many responsibilities to each of the firm's specific departments, while in medium-sized firms management is more simple and consequently the Top Management can get more directly involved".

\section{The Situation of Outsourcing}

Concerning the situation of IS outsourcing in large firms (question 5), most of the experts we interviewed state that more outsourcing would be needed and only 2 experts (13.3\%) argue that no more outsourcing is required. According to those who support the first view, 
“computer experts cannot know and much less control all the changes that take place every day"; for this reason, "one part must be outsourced"; "it is a mistake not to outsource, as it is impossible to be up to date in everything; in my opinion, firms would have to outsource more and focus their efforts on their true objectives". They even point out that firms which do not outsource "either have very little development or are making a mistake that leads to evident cost inefficiency".

Similarly, it is said that, "although technology departments must be considered strategic for the business, it is also true that some of the tasks undertaken in these departments are less strategic than others and, therefore, can be outsourced as long as the IS department does not lose the control of processes". Many even predict in this respect that "the percentage -of those which do not outsource- will eventually decrease", and the phenomenon of IS outsourcing is "unstoppable".

The two interviewees who think that no more outsourcing is needed openly criticise this business practice; the first one states that "my firm has outsourced and the results have been bad or very bad... I do not mean that a poor service is deliberately offered; what I mean is that it comes as a result of trying to manage a complex, particular and changing business environment externally". The second interviewee thinks that "all firms should aspire to the total absence of outsourcing".

In the sixth question, we cannot find homogeneous answers that can be classified within a specific pattern. When experts were asked why they thought the largest firms, service sector firms and financial institutions outsource more than smaller firms and those belonging to the industrial sector, they said the following with respect to sectors:

"the financial sector outsources more due to the constant changes required", whereas "in the industrial sector, the functional know-how is more important that its representation in the IS, and there is not so much variability; processes are more stable" .

And regarding size, they explained that... "large firms have more heterogeneous computer systems where it is more difficult to control all the environments", and even "the largest firms are more dynamic and innovative in all aspects". Finally, the economic factor is also important. Some interviewees argued that... " outsourcing, though effective, is expensive, and 
large firms as well as those with greater profit-margins, like the financial and service sectors, can afford it".

Question seven referred to the reasons for the adoption of outsourcing and our results during the first round had shown that large firms resorted to outsourcing as a way of improving their IS rather as a means to save costs. Most of the experts interviewed in the second round confirmed this result, while 4 of them declared that this conclusion was not correct. Those who supported the first view argued that "nowadays, any expert that loses touch of the new developments and the evolution can easily become out of date. A firm dedicated to IS -the outsourcing provider- will have available better means for that expert to be up to date", that is to say, "with the speed at which changes take place in the IT sector, outsourcing is the only way to keep oneself up to date". Some people think that "the only reason to opt for outsourcing must be IS improvement and the corresponding optimisation of resources, while the firm focuses on its own functions. Any outsourcing decision whose objective is cost reduction is doomed to failure, if price takes priority over service quality".

On the opposite side are the experts who argued that the reasons to outsource can be summarised in a reduction of costs; in other words, "firms outsource when saving is the priority".

In relation to the most significant factors for reluctance to outsource (question 8), interviewees were asked to give their opinion about the results of the first round, namely: the fear that outsourcing can cause a firm to lose the capacity to manage its own IS in future is worse than the mistrust of the providers of these services.

Most interviewees (80\%) agreed with this conclusion; for example, they argue that "outsourcing IS means outsourcing the firm's global knowledge and this is risky. Employees belonging to the IS staff are those who accumulate more global knowledge within the organisation, because many managerial processes are at their hands sooner or later, now that everything is computerised"; this is why another interviewee argues that "the know-how must stay in the firm, so that it can be manageable; a firm should only outsource what does not provide value, thus avoiding risks for the company. It should outsource processes that can be considered commodities, not business-support processes". 
For these reasons, also in this question, experts advocate selective outsourcing and having several providers: "Firms should never leave 100\% of the business at the hands of a third party, it is of vital importance to retain control internally; by doing that, mistrust disappears and firms work on a collaborative model". "Once total outsourcing has been carried out, going back is very difficult and generally very traumatic". "IS must be outsourced counting on several providers, making a distribution of functions and rotations over time, so that dependence on one provider in particular is reduced".

Those who disagree with this conclusion say that we should not be reluctant to outsource, because "it will be the future and mutual confidence (between provider and client) along with a rooted, practical ethic should exist".

During the first round of our research work, we concluded that IS outsourcing does not modify or, if anything, improves the IS manager's job, and we cannot say it is detrimental to that job. $40 \%$ of the interviewees confirmed this result in the second round, only $20 \%$ disagreed with this conclusion and $40 \%$ answered with some nuances saying that it depends on other factors.

In the first case, those who claim that outsourcing does not modify or, if anything, improves the job argue that "it allows IS executives to dedicate more time to the strategic orientation of their department"; furthermore, with outsourcing, "information and experience are brought in from outside, thus leading to a deeper knowledge of the environment the IS manager has to face. There is also a liberation of the time originally dedicated to the outsourced IS". On the contrary, those who argue that outsourcing is detrimental to their job are openly against this practice, and suggest that "it neither modifies nor improves their job; it is meant to create total dependence on it". Those who think that it depends on other factors explain that "although outsourcing certain routine tasks performed by IS people can mean a reduction of the "repulsive" work load (that which does not provide personal satisfaction and does not mean a challenge or an opportunity for improvement), in my own experience, it has not led to an improvement of the "propulsive" part (that related to improvement and challenge)", and argue that "it changes the (IS manager's) profile and functions; it is not necessary to be up to date in terms of technological evolution, but it is indeed necessary to dedicate more time to management and strategies". 
Finally, concerning the future of outsourcing, we concluded in the first round that financial and insurance institutions as well as service firms are considering the possibility of reducing and eliminating their internal IS to adopt outsourcing, a possibility that industrial firms have not considered at all. Answers to this question in the second round are very varied. Some try to justify this result saying that "the first group of firms "manufacture" a product that changes a lot and can very quickly adapt to the changes imposed by the market. It is difficult to achieve high adaptability exclusively with internal resources and having to drag a very complex IS structure. Instead, industry works more slowly, which is probably why it does not have such an urgent need to outsource"; others warn of the danger total outsourcing entails "it is a wrong policy; a firm cannot permanently be at the hands of an external organisation, especially in times of great staff mobility. It would be advisable to achieve some kind of balance between internal and external staff". Although, in general terms, they all predict the growth of outsourcing. As one interviewee puts it, "outsourcing will grow in a geometrical progression, even in firms belonging to the industrial sector".

\section{DISCUSSION AND CONCLUSIONS}

IS outsourcing is a constantly growing phenomenon that evolves through the provision of new services and is spreading to different geographical areas. The Delphi method is gaining ground among qualitative methods in the IS area. This is why we decided to apply a variant of this method in our attempt to obtain information about the assessment IS managers make of IS outsourcing in the case of large Spanish firms. The variant we used is a normative Delphi, as we have not tried to predict, but to check the views of some experts about a specific matter.

According to the experts interviewed, large Spanish firms allocate few resources to their IS departments, in terms of both staff numbers and budget. On the other hand, they agree that the position and hierarchical dependence of the IS manager, who reports to the Finance or Administration areas in one third of these large firms, is not correct. These two facts give us to understand that this crucial business area is neglected in quite a few Spanish firms. If we add to this the fact that the Top Management of the largest Spanish firms is less committed to IS, we can conclude that the environment in which outsourcing is developing seems still relatively hostile to this business practice. 
This is perhaps the reason why the outsourcing level in large Spanish firms, though high, is still not excessive. Most experts agree that those firms should outsource more. Regarding the strategic contribution made by IT, experts usually advocate selective outsourcing, reflecting the view that is most commonly defended in the literature on this issue (Lacity, Willcocks and Feeny, 1996). Larger firms along with financial and insurance institutions are those which outsource the most. Experts justify it, in the first case, by the use of more heterogeneous technologies and the resulting difficulty to cover all the areas, and in the second case, by the constant change that is characteristic of these sectors. This confirms that outsourcing is no longer confined to small firms with limited resources; in fact, it has proved suitable to large companies (Teng, Cheong and Grover, 1995: 77) and has also become a good option for sectors where IS activities are seen as core competencies (McLellan, Marcolin and Beamish, 1995).

Experts agreed that the main goal sought through IS outsourcing is IS improvement rather than cost control. In this sense, they argued that resorting to outsourcing is often the only way to be up to date, thanks to the technical means service providers count on. This conclusion is similar to that of Slaughter and Ang (1995) who saw the trend to outsource as a "response to an increasingly volatile enviroment where there is an economic imperative to adquire quickly the necessary skills at the lowest cost". Interviewees also said that the most relevant risk involved in outsourcing is that firms might lose the capacity to manage their own IS, since outsourcing IS is like outsourcing the organisation's global knowledge. For this reason, and in order to avoid that risk, they once again recommended firms to opt for the selective outsourcing of those functions that add less value to the business and to have several providers in order to avoid the dependence on one provider in particular. These recommendations had already been backed by previous studies (Currie, 1998; Lacity, Willcocks and Feeny, 1996; Lacity and Willcocks, 1998; Willcocks, Lacity and Kern, 1999).

Along the lines of other research papers (Corbett, 1994: 20; Clark, Zmud and McCray, 1995: 229), our panel of experts concluded that outsourcing can be a way to improve the IS manager's work post, especially when suppliers provide information and experience, and when it liberates time dedicated to routine tasks associated with IT management. In short, it was checked that outsourcing is an irreversible phenomenon and that even some sectors, like 
that represented by financial and insurance institutions, are thinking about resorting even more to this form of IS management, thus reducing their internal IS services.

The Delphi method helped us to confirm in the second round the conclusions that we had reached in the first round. Indeed, in most of the questions, interviewees considered the results appropriate or correct. Similarly, it gave us the chance to understand the reasons behind those results, because, when asked to give their opinions, the experts interviewed explained why they mostly agreed, or much less often disagreed, with those results.

\section{REFERENCES}

Bradley, L, and Steward, K. (2002), “A Delphi study of the drivers and inhibitors of Internet banking", International Journal of Bank Marketing, Vol 20 No 6, pp. 250-260.

Bradley, L. and Stewart, K. (2003), “A Delphi study of Internet banking”, Marketing Intelligence and Planning, Vol 21 No 5, pp. 272-281.

Buckley, Ch. (1995), “Delphi: a methodology for preferences more than predictions”, Library Management, Vol 16 No 7, pp. 16-19.

Clark, T.D.; Zmud, R.W. and McCray, G.E. (1995), “The Outsourcing of Information Services: Transforming the Nature of Business in the Information Industry", Journal of Information Technology, Vol 10, pp. 221-237.

Corbett, M.F. (1994), “Outsourcing and the New IT Executive. A Trends Report”, Information Systems Management, Vol 11 No 4, pp. 19-22.

Currie, W.L. (1998), "Using multiple suppliers to mitigate the risk of IT outsourcing at ICI and Wessex Water", Journal of Information Technology, Vol 13 No 3, pp. 169-180.

Dekleva, S. and Zupancic, J. (1996), “Key issues in information systems management: a Delphi study in Slovenia", Information \& Management, Vol 31 No 1, pp. 1-11.

Dexter, A.S. , Janson, M.A., Kiudorf, E. and Laast-Laas, J. (1993), “Key Information technology issues in Estonia", Journal of Strategic Information Systems, Vol 12 No 2, pp. 139-152.

Dhaliwal, J.S. and Tung, L.L. (2000), “Using group support systems for developing a knowledge-based explanation facility", International Journal of Information Management, Vol 20 No 2, pp. 131-149. 
Doke, E.R. and Swanson, N.E. (1995), “Decision variables for selecting prototyping in information systems development: a Delphi study of MIS managers", Information \& Management, Vol 29 No 4, pp. 173-182.

Forrester (2004), “Europe's IT services spending will grow by 57 percent from 2003 to 2008", http://www.t-

systems.com/ipl2/statistics/923/downloads/press_kits/IPK2004/statement_Forrester_Bennet.pd f.

Frauenheim, E.(2004), “Gartner: Outsourcing to grow, but deals to shrink", http://news.com.com/Gartner+Outsourcing

+to+grow, +but+d.../2100-1011_3-5162244.htm.

Grupo Penteo (2003), “La externalización de los servicios TIC en España. Año 2003”. http://www.penteo.com.

Gutierrez, O. (1989), “Experimental Techniques for Information Requirements Analysis”, Information \& Management, Vol 16 No 1, pp. 31-43.

Hayne, S.C. and Pollard, C.E. (2000), "A comparative analysis of critical issues facing Canadian information systems personnel: a national and global perspective", Information \& Management, Vol 38 No 2, pp. 73-86.

Kaynak, E.; Bloom, J. and Leibold, M. (1994), "Using the Delphi technique to predict future tourism potential", Marketing Intelligence \& Planning, Vol 12 No 7, pp. 18-29.

Keil, M.; Tiwan, A. and Bush, A. (2002), "Reconciling user and project manager perceptions of IT project resik: A Delphi study", Information Systems Journal, Vol 12 No 2, pp. 103-119.

Lacity, M.C.; Willcocks, L.P. and Feeny, D.F. (1996), "The Value of Selective Sourcing”, Sloan Management Review, Vol 37 No 3, pp. 13-25.

Lacity, M.C. and Willcocks, L. (1998), "An empirical investigation of Information Technology sourcing practices: lessons from experience", MIS Quarterly, Vol 22 No 3, pp. 363-408.

Li, S; Davies, B.; Edwards, J.; Kinman, R. and Duan, Y. (2002), “Integrating group Delphi, fuzzy logic and expert systems for marketing strategy development: the hybridisation and its effectiveness", Marketing Intelligence \& Planning, Vol 20 No 5, pp. 273-284.

Loo, R. (2002), “The Delphi method: a powerful tool for strategic management”, Policing: an International Journal of Police Strategies \& Management, Vol 25 No 4, pp. 762-769. 
Madu, Ch.; Kuei, Ch. and Madu, A.N. (1991), "Setting priorities for the IT industry in Taiwan A Delphi Study", Long Range Planning, Vol 24 No 5, pp. 105-118.

McLellan, K., Marcolin, B. and Beamish, P. (1995), "Financial and strategic motivations behind IS outsourcing", Journal of Information Technology, Vol 10 No 4, pp. 299-321.

Mulligan, P. (2002), "Specification of a capability-based IT classification framework", Information \& Management, Vol 39 No 8, pp. 647-658.

Okoli, C. and Pawlowski, S.D. (2004), “The Delphi method as a research tool: an example, design considerations and applications", Information \& Management, Vol 42 No 1, pp. 15-29. Pérez, V.L. and Schüler, R. (1982), “The Delphi method as a tool for Information requirements specifications", Information \& Management, Vol 5, pp. 157-167.

RrhhMagazine (2004), “El mercado del outsourcing informático se duplicó entre 1999 y 2003", http://www.rrhhmagazine.com/noticias.asp?id=633.

Shi, N. and Bennet, D. (2001), "Benchmarking for information systems management using issues framework studies: content and methodology", Benchmarking: An international Journal, Vol 8 No 5, pp. 358-375.

Slaughter, S. and Ang, S. (1995), "Information Systems employment structures in the USA and Singapore: a cross-cultural comparison", Information Technology \& People, Vol 8 No 2, pp. 1736.

Teng, J.; Cheong, M.J. and Grover, V. (1995), “Decisions to Outsource Information Systems Functions: Testing a Strategy-Theoretic Discrepancy Model”, Decision Sciences, Vol 26 No 1, pp. $75-103$.

Ventura Fernández, R. (2003), “La utilización de la técnica Delphi en el diseño de escenarios. Aplicación en el negocio de la televisión por cable", Revista Europea de Dirección y Economía de la Empresa, Vol 12 No 3, pp. 177-202.

Willcocks, LP., Lacity MC. and Kern, T. (1999), "Risk mitigation in IT outsourcing strategy revisited: longitudinal case research at LISA", Journal of Strategic Information Systems, Vol 8 No 3, pp. 285-314. 
Table I: Characteristics of firms and IS departments in both rounds.

\begin{tabular}{|c|c|c|c|c|c|}
\hline & \multicolumn{2}{|c|}{$1^{\text {st }}$ round } & \multicolumn{2}{|c|}{$2^{\text {nd }}$ round } \\
\hline & & $\mathbf{N}$ & $\%$ & $\mathbf{N}$ & $\%$ \\
\hline \multirow{4}{*}{ Staff } & $0-50$ & 22 & 6.2 & 2 & 13.3 \\
\hline & $51-500$ & 202 & 56.6 & 8 & 53.4 \\
\hline & Over 500 & 132 & 36.9 & 5 & 33.3 \\
\hline & Lost & 1 & 0.3 & 0 & 0.0 \\
\hline \multirow{4}{*}{$\begin{array}{l}\text { Sales } \\
\text { (millions of } \\
€ \text { ) }\end{array}$} & Up to 30 & 36 & 10.1 & 2 & 13.3 \\
\hline & More than 30 and up to 300 & 227 & 63.6 & 7 & 46.7 \\
\hline & More than 300 & 93 & 26.0 & 6 & 40.0 \\
\hline & Lost & 1 & 0.3 & 0 & 0.0 \\
\hline \multirow{3}{*}{ Sector } & Industry & 210 & 58.8 & 9 & 60.0 \\
\hline & Services & 118 & 33.1 & 3 & 20.0 \\
\hline & $\begin{array}{l}\text { Financial and Insurance } \\
\text { Institutions }\end{array}$ & 29 & 8.1 & 3 & 20.0 \\
\hline \multirow{5}{*}{$\begin{array}{l}\text { Autonomou } \\
\text { s } \\
\text { Community } \\
\text { (Region) }\end{array}$} & Madrid & 117 & 32.8 & 5 & 33.3 \\
\hline & Catalonia & 85 & 23.8 & 2 & 13.3 \\
\hline & Valencian Community & 38 & 10.6 & 2 & 13.3 \\
\hline & Basque Country & 22 & 6.2 & 1 & 6.7 \\
\hline & Others & 95 & 26.6 & 5 & 33.3 \\
\hline \multirow{4}{*}{ IS Staff } & 1-10 Employees & 240 & 67.2 & 9 & 60.0 \\
\hline & 11-100 Employees & 96 & 26.9 & 6 & 40.0 \\
\hline & 101-400 Employees & 5 & 1.4 & 0 & 0.0 \\
\hline & Lost & 16 & 4.5 & 0 & 0.0 \\
\hline \multirow{5}{*}{$\begin{array}{l}\text { Budget } \\
\text { percentage } \\
\text { allocated to } \\
\text { IS } \\
\end{array}$} & $0-4$ & 133 & 37.2 & 8 & 53.3 \\
\hline & $5-10$ & 61 & 17.1 & 3 & 20.0 \\
\hline & $11-30$ & 18 & 5.1 & 1 & 6.7 \\
\hline & Lost & 145 & 40.6 & 3 & 20.0 \\
\hline & Mean & 7.4 & & 7.0 & \\
\hline \multirow{6}{*}{$\begin{array}{l}\text { IS } \\
\text { Manager's } \\
\text { length of } \\
\text { service }\end{array}$} & Median & 5.0 & & 4.0 & \\
\hline & Standard deviation & 6.2 & & 5.9 & \\
\hline & Minimum & 1.0 & & 1.0 & \\
\hline & Maximum & 30.0 & & 1 & \\
\hline & & & & 9.0 & \\
\hline & Lost & 15 & 4.2 & 0 & 0.0 \\
\hline \multirow{9}{*}{$\begin{array}{l}\text { IS } \\
\text { Manager's } \\
\text { age }\end{array}$} & Mean & 41.0 & & 4 & \\
\hline & Median & 40.0 & & 1.0 & \\
\hline & Standard deviation & 7.9 & & 4 & \\
\hline & Minimum & 22.0 & & 3.0 & \\
\hline & Maximum & 60.0 & & 8.3 & \\
\hline & & & & 2 & \\
\hline & & & & 9.0 & \\
\hline & & & & 5 & \\
\hline & Lost & 14 & 3.9 & 0 & 0.0 \\
\hline IS & Male & 321 & 89.9 & 13 & 86.7 \\
\hline \multirow{2}{*}{$\begin{array}{l}\text { Manager's } \\
\text { sex }\end{array}$} & Female & 25 & 7.0 & 2 & 13.3 \\
\hline & Lost & 11 & 3.1 & 0 & 0.0 \\
\hline \multirow{5}{*}{$\begin{array}{l}\text { Work post } \\
\text { of the IS } \\
\text { Manager's } \\
\text { direct } \\
\text { superior }\end{array}$} & Chief Executive Officer & 193 & 54.1 & 10 & 66.7 \\
\hline & Finance and Accounting & 101 & 28.3 & 4 & 26.6 \\
\hline & IS manager of the & 17 & 4.8 & 0 & 0.0 \\
\hline & corporation & 20 & 5.6 & 1 & 6.7 \\
\hline & $\begin{array}{l}\text { Organisation/Planning/Engi } \\
\text { neering }\end{array}$ & 26 & 7.3 & 0 & 0.0 \\
\hline
\end{tabular}


Table II: IS Managers' View about Outsourcing

\begin{tabular}{|c|c|c|c|}
\hline \begin{tabular}{c}
\multicolumn{2}{c}{ Questions } \\
The environment around IS outsourcina
\end{tabular} & Answers & $\mathrm{N}$ & $\%$ \\
\hline $\begin{array}{l}\text { 1. Most IS or computer departments of the firms } \\
\text { interviewed have between } 1 \text { and } 10 \text { employees. Do you } \\
\text { think this is an adequate number considering that we are } \\
\text { talking about large firms? Give your opinion. }\end{array}$ & $\begin{array}{l}\text { Scant } \\
\text { Adequate } \\
\text { It depends }\end{array}$ & $\begin{array}{l}8 \\
4 \\
3\end{array}$ & $\begin{array}{l}53.3 \\
26.7 \\
20.0\end{array}$ \\
\hline $\begin{array}{l}\text { 2. Most IS departments count on a percentage of } 0 \text { to } 4 \% \\
\text { of the firm's total budget. Do you consider this percentage } \\
\text { adequate for such large firms? Give your opinion. }\end{array}$ & $\begin{array}{l}\text { Scant } \\
\text { Adequate }\end{array}$ & $\begin{array}{l}1 \\
0 \\
5\end{array}$ & $\begin{array}{l}66.7 \\
33.3\end{array}$ \\
\hline $\begin{array}{l}\text { 3. } 30 \% \text { of the firms interviewed have an IS manager who } \\
\text { must report to Finance and/or Administration. Does this } \\
\text { hierarchical dependence seem appropriate to you? Give } \\
\text { your opinion. }\end{array}$ & $\begin{array}{l}\text { Inappropriate } \\
\text { Appropriate } \\
\text { It depends }\end{array}$ & $\begin{array}{l}1 \\
2 \\
2 \\
1\end{array}$ & $\begin{array}{r}80.0 \\
13.3 \\
6.7\end{array}$ \\
\hline $\begin{array}{l}\text { 4. In the largest firms, the Top Management's involvement } \\
\text { in the IS seems lower than in smaller firms. Could you give } \\
\text { an opinion about this? }\end{array}$ & & & \\
\hline The IS Outsourcing Situation & & & \\
\hline $\begin{array}{l}\text { 5. Out of } 357 \text { valid questionnaires received, } 51 \text { state that } \\
\text { no IS services have been outsourced in their firm. What do } \\
\text { you think about this result? }\end{array}$ & $\begin{array}{l}\text { Outsourcing } \\
\text { more } \\
\text { No more } \\
\text { outsourcing }\end{array}$ & $\begin{array}{l}1 \\
3 \\
3\end{array}$ & $\begin{array}{l}86.7 \\
13.3\end{array}$ \\
\hline $\begin{array}{l}\text { 6. The largest firms, along with service and sector firms, } \\
\text { and financial and insurance institutions outsource more } \\
\text { than smaller firms and firms belonging to the industrial } \\
\text { sector. Could you give us your opinion about this? }\end{array}$ & $\begin{array}{l}\text { Heterogeneou } \\
\text { s answers }\end{array}$ & & \\
\hline $\begin{array}{l}\text { 7. Firms resort to outsourcing as a way of improving their } \\
\text { IS rather than as a means to save costs. What would you } \\
\text { say about this statement? }\end{array}$ & $\begin{array}{l}\text { It is } \\
\text { It is } \\
\text { corre }\end{array}$ & $\begin{array}{l}1 \\
1 \\
4\end{array}$ & $\begin{array}{l}73.3 \\
26.7\end{array}$ \\
\hline $\begin{array}{l}\text { 8. A great number of firms argue that outsourcing can } \\
\text { deprive the organisation of the capacity to manage its own } \\
\text { IS in the future, and this fear is stronger than the mistrust } \\
\text { of those who provide these services. We would like to } \\
\text { know your opinion about this. }\end{array}$ & $\begin{array}{l}\text { I agree } \\
\text { I disagree } \\
\text { It depends }\end{array}$ & $\begin{array}{l}1 \\
2 \\
2 \\
1\end{array}$ & $\begin{array}{r}80.0 \\
13.3 \\
6.7\end{array}$ \\
\hline $\begin{array}{l}\text { 9. It has been concluded that IS outsourcing does not } \\
\text { modify or, if anything, improves the IS manager's job, but } \\
\text { we cannot say it is detrimental to that job. What do you } \\
\text { think about this conclusion? }\end{array}$ & $\begin{array}{l}\text { I agree } \\
\text { I disagree } \\
\text { It depends }\end{array}$ & $\begin{array}{l}6 \\
3 \\
6\end{array}$ & $\begin{array}{l}40.0 \\
20.0 \\
40.0\end{array}$ \\
\hline $\begin{array}{l}\text { 10. Finance and insurance institutions followed by service } \\
\text { firms are considering the possibility of reducing or } \\
\text { eliminating their internal IS services, opting for } \\
\text { outsourcing. Industrial firms do not consider this }\end{array}$ & $\begin{array}{l}\text { Heterogeneou } \\
\text { s answers }\end{array}$ & & \\
\hline
\end{tabular}

